\title{
Paradigma Politik Nahdlatul Ulama (NU) dalam Bernegara
}

\section{Masmuni Mahatma}

STAIN Syaikh Abdurrahman Siddik Bangka Belitung, Indonesia

Masmuni2004@yahoo.com

\begin{abstract}
Abstrak
NU selalu terlihat politis. Latar sejarahnya sendiri sebagai gejala politis, minimal, dalam perspektif politik Islam, baik di level nasional maupun internasional. Spirit lahirnya sebagai jam'iyyah berbasis simbol dan kekuatan ulama (kiai), senantiasa mengundang banyak tanya dan keterkaguman. Ibarat pedang, NU memiliki dua mata yang jernih dan tajam serta sangat berbahaya kalau dibiarkan menusuk sesuatu, termasuk menyangkut perpolitikan tanah air. Paradigma politik NU serba unik, cair, tapi menggetarkan.
\end{abstract}

Kata kunci: NU, Paradigma, Politik.

Received: 03-05-2017; accepted: 14-06-2017; published: 01-07-2017 


\section{A. Pendahuluan}

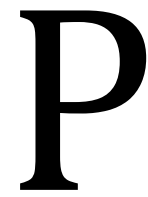

erjalanan bangsa Indonesia selama kurang lebih enam dasawarsa dalam mengisi kemerdekaan ternyata sedang dihadapkan dengan berbagai permasalahan yang krusial, seperti tingginya angka kemiskinan, praktik korupsi, mafia anggaran, mafia hukum, dan lain-lain. Permasalahan itu ternyata memberi dampak terhadap pelapukan proses keadaban bangsa kita, terutama dalam membangun kesadaran yang berlandaskan pada moralitas. Tak heran, jika keadaban bangsa ini sedang dipertaruhkan dengan himpitan persoalan sosial-ekonomi, politik, dan agama.

Nahdlatul Ulama (NU), sebagai organisasi Islam terbesar di Indonesia ikut bertanggung jawab untuk memberikan kontribusinya dalam mewujudkan cita-cita keadaban bangsa. Sebab NU dilahirkan tidak hanya ditujukan kepada jamaahnya, namun bagaimana NU bisa memberikan sumbangsih kepada bangsa. Dan NU telah berusaha ikut serta dalam menawarkan jalan keadaban yang bisa diberikan kepada umat maupun bangsa ini sedari awal sejarah kelahiran dan dinamika eksistensinya. ${ }^{1}$

Pertama, NU telah merumuskan konsep mabadi' khoiro ummat (prinsip dasar umat terbaik) yang didasarkan pada orientasi moral sebagai perubahan sosial-ekonomi masyarakat. Pengukuhan moralitas tersebut bertumpu pada as-shidq (kejujuran) dan alamanah (tanggung jawab). Kedua, dalam ranah keagamaan, NU telah berhasil merumuskan gagasan dasar tentang tawassuth (moderat), tasamuh (toleransi), tawazun (keseimbangan), dan i'tidal (keadilan).

Ketiga, NU telah memelopori penerimaan dan pengamalan Pancasila sebagai asas bernegara dan bermasyarakat yang bisa diterima oleh warga negara Indonesia yang majemuk. ${ }^{2}$ Atas dasar semua ini NU wajib memelihara dan mempertahankan asas-asas dasar kenegaraan yang telah dirumuskan oleh para pendahulu, melalui darah para syuhada dan tinta para ulama, selaku pewaris para Nabi Allah 警.

Proses yang dinamis dalam tubuh NU di negara ini seperti sebuah perahu yang mendayung diantara dua pulau, yaitu sebagai gerakan sosial keagamaan dan keumatan

${ }^{1}$ Simak juga "Kesetian NU Tak Pernah Luntur" (Surabaya: AULA, Agustus 2007), pp. 10-7. Sekadar taukid, bahwa AULA merupakan majalah NU yang dikelola oleh PW NU Jawa Timur dan sampai kini masih terus mengada untuk pencerahan kesejarahan dan fakta-fakta keterlibatan NU dalam kancak sosial kebangsaan.

${ }^{2}$ Lihat AULA, Agustus 2007, p. 12. Namun demikian, perlu juga dimafhumi bahwa penegasan ini sering dikutip oleh banyak penulis baik dari dalam maupun luar negeri. 
sekaligus dan kekuatan politik (political power) berbasis massa atau umat yang terus melekat dalam gerakan-gerakan kultural, nalar, dan aktualisasi spirit sosial kebangsaannya. Tak berlebihan jika seorang tokoh Dawam Rahardjo mensinyalir bahwa dalam kenyataan sejarah perkembangan politiknya, NU justru tidak menampakkan konservatismenya, terutama sekali menyangkut perilaku sosial politiknya. ${ }^{3}$

Masa depan NU ditentukan oleh kemampuannya menggunakan biduk secara tepat di tengah gelombang politik nasional dan tuntutan sosial sebagai konsekuensi logis gerakan modernitas politik. Dan di sisi lain NU senantiasa dipandang sebagai representasi Islam tradisional(is) Indonesia yang sedemikian mengakar dan memiliki paradigma sosial yang terbilang tangguh. Wajar kalau Dawam Rahardjo pun mengamini tesis Asep Saeful Muhtadi bahwa NU memang memiliki komunikasi politik yang layak diperhitungkan. NU, tulisnya, memang bukan partai politik tapi harus menjalankan komunikasi politik demi kemaslahatan umat yang dinaunginya. Sebab, kalau dicermati sedalam mungkin, walau bukan partai politik, NU merupakan organisasi politik atau organisasi sosial kemasyarakatan yang mau tak mau mesti berpolitik. Sehingga dari rahim NU sendiri lahir partai-partai politik, baik di masa awal keberadaan hingga belakangan ini. ${ }^{4}$ Bahkan, NU dulu pernah meresmikan wajah dan napasnya sebagai partai politik, dan menjadi pesaing dari PKI dan Masyumi.

Ilustrasi singkat di atas rasanya cukup dijadikan salah satu media untuk merefleksikan lebih jauh bagaimana peran ideal dan paradigma politik NU sebagai salah satu organisasi kemasyarakatan terbesar di Indonesia. Dan tentu saja paradigma politik NU terus sejalan dan senafas dengan prinsip-prinsip dasar Ahlussunnah Wal Jama'ah, yang telah lama diamalkan dan diajarkan para pendiri (mu'assis) Jam'iyyah ini sendiri dalam kancah perpolitikan secara makro. Sehingga soal Khittah 1926 pun tiada henti didiskusikan, baik oleh tokoh-tokoh yang menjadi kekuatan-kekuatan internal NU,

3 Cermati tulisan M. Dawam Rahardjo, "Nahdlatul Ulama dan Politik" dalam buku yang ditulis oleh Asep Saeful Muhtadi, Komunikasi Politik Nahdlatul Ulama; Pergulatan Pemikiran Politik Radikal dan Akomodatif, (Jakarta: LP3ES, November 2004), p. xxiv. Bahkan pada halaman berikutnya Dawam Rahardjo lebih tegas mengatakan bahwa NU sendiri sebenarnya memang lahir sebagai gejala politik, paling tidak untuk menjaga otoritas politik Islam di era awal kebangkitan bangsa ini. (xxix). Dan karena itu sering kali perilaku politik NU kadang tampak dilematis atau tepatnya terlihat ambigu; menampilkan diri sebagai kekuatan kultur keumatan tapi juga memainkan citra dirinya selaku political power yang tak bisa diremehkan di kancah dunia.

4 Ibid., p. xxxii. 
pengamat, akademisi, hatta sekian komunitas eksternal NU pada umumnya dari dalam maupun luar negeri. ${ }^{5}$

Dari penjabaran latar belakang di atas, ada beberapa pertanyaan yang mesti dicarikan analisa dasarnya, yakni apa saja dasar-dasar politik Islam? Apakah yang menjadi konsep dasar politik Ahlussunnah Wal Jamaah? Apa yang menjadi dasar paham keagamaan NU? Bagaimanakah paradigma politik yang dibangun dalam tubuh NU? Bagaimana bentuk ideal peran NU dalam kancah politik di Indonesia?

\section{B. Dasar Etik Politik Islam Secara Umum}

Dalam tataran historis maupun normatif ajaran, Islam dan politik mempunyai keterkaitan yang sangat kuat, bila keduanya dipahami sebagai sarana untuk menata kehidupan manusia. Islam tidak hanya dijadikan sebagai "alat legitimasi" terhadap kekuasaan (legitimate of power). Politik yang dipahami secara parsial dengan mengenyampingkan pengertian yang lebih komprehensif, tentu akan mengaburkan makna dan menafikan kontribusi Islam terhadap dunia politik itu sendiri. Dengan demikian Islam perlu dijadikan sebagai sumber inspirasi kultural dan kerangka paradigmatik yang bersifat dinamik dalam pemikiran politik. ${ }^{6}$

Ajaran dan pemikiran politik Islam sebagai hasil sistematisasi kerangka agama Islam dan tradisi-tradisi kaum muslimin di bidang politik, muncul sejalan dengan kecepatan ekspansi Islam keluar jazirah Arab. Hal ini menyebabkan problematika baru tentang cara pengaturan (kekuasaan) negara, disamping konsekuensi logis munculnya kelompok-kelompok kepentingan. Kelompok-kelompok ini, baik yang berbasis sosial budaya atau sosial keagamaan tertentu merasa telah memberi kontribusi dalam proses jihad.7 Rasanya layak pula diapresiasi apa yang dinyatakan oleh Abu A'la Al Maududi bahwa agama dalam kekuasaan bisa bertambah kuat, adapun kekuasaan dalam agama itu bisa lebih eksis dan paripurna. ${ }^{8}$ Dan menyangkut kaitan esensial-praktis antara

5 Untuk menyebut beberapa tokoh dan akademisi yang mengamati NU antara lain: Mahbub Djunadi, Sudirman Tebba, Mahrus Irsyam, Ahmad Mansur Suryanegara, Saifullah Ma'shum, Kacung Marijan, Usman Yatim, Masduki Baidlawi, Fachry Ali, Moeslim Abdurrahman, Aswab Mahasin, Denny J.A., A. Gaffar Karim, As'ad Said Ali, Ahmad Baso, Einar Martahan Sitompul, J. Cristiadi, Dedi Djamaluddin Malik, Greg Fealy, Greg Barton, Andree Fellard, Kang Young Soon, dan lain sebagainya.

${ }^{6}$ Ridwan, Paradigma Politik NU: Relasi Sunni-NU dalam Pemikiran Politik, (Yogyakarta: Pustaka Pelajar, 2004), pp. 1-2.

7 Ibid., p. 3.

8 Eko Maulana Ali Suroso, Energi Agama dalam Kuasa, Merapikan Nilai-Nilai Agama dalam Pemerintahan, (Bandung: Mutiara Press, 2008), p. 182. Perhatikan pula pengantar M. Dawam Rahardjo 
agama dan politik (kekuasaan) negara sebetulnya sudah lama dijabarkan oleh sejumlah tokoh besar seperti Ibn Sina, Al Farabi, Al Kindi, Al-Ghazali, dan tokoh-tokoh di seberang jalur teologis macam Plato, Arestoteles, dan lain-lain.

Bisa pula dimaknai bahwa ikhtilaf atau perbedaan pemikiran politik dalam Islam ini tampaknya lebih disebabkan oleh cara dan semangat menafsirkan teks-teks normatif agama, disamping perbedaan-perbedaan sosial budaya yang melingkarinya. Perhatian utama Alquran adalah memberikan landasan etik bagi terbangunnya sistem politik yang dilandasi oleh prinsip tegaknya masyarakat adil dan bermoral (berakhlak). Dan salah satu yang menjadi isu paling kontroversial dalam sejarah pemikiran politik Islam adalah masalah khilafah. Setelah Nabi Muhammad wafat, masyarakat Islam yang baru seketika dihadapkan pada suatu krisis konstitusional mengenai prosedur pemilihan kepala negara untuk menggantikan posisi Nabi Muhammad sebagai teladan pemimpin terluhur dari segenap komunitas Islam. Sebab di dalam Alquran dan AsSunnah tidak ada ketentuan yang benar-benar jelas, tuntas, final, tanpa terganggu lagi dengan olah pikiran manusia tentang mekanisme, bentuk pemerintahan, dan perwajahan lembaga politik-lembaga politik itu sendiri.

Gambaran dinamis di atas bisa dimaknai bahwa diamnya Alquran menyangkut masalah ini memberikan suatu jaminan dan peluang bagi umat Islam untuk terus menerus melakukan analisa, kajian, dan otokritik konstruktif dalam memformulasikan sistem politiknya sesuai dengan kebutuhan masyarakat. Oleh karena itu, mengkaji pemikiran politik dan sistem ketatanegaraannya dalam Islam harus diorientasikan pada upaya menerjemahkan cita-cita politik Islam dengan cara membuat format dan sistem politik yang sesuai dengan etika Alquran dan As-Sunnah. ${ }^{9}$

Populasi komunitas muslim yang terbilang sangat luar biasa menyebabkan banyak pihak ingin melirik bahkan mengusik ketentraman dan keharmonisan kaum muslimin dalam melaksanakan rutinitas kehidupan, terutama menyangkut pergulatan sosial politiknya. Sehingga lahir banyak pemikiran-pemikiran baru yang seolah-olah ingin memperbaiki peradaban Islam, namun pada hakikatnya berorientasi juga pada singgasana kekuasan yang dengan itu mereka bisa menyalurkan konsep-konsep dan

dalam buku "Komunikasi Politik Nahdlatul Ulama" karya Asep Saeful Muhtadi, (Jakarta: LP3ES, 2004), bahwa Islam sendiri, konon, adalah al-Din wa al-Dawlah.

${ }^{9}$ Ibid., p. 182. 
buah pemikirannya tentang Islam itu sendiri. Inilah yang belakangan mengemuka di Indonesia.

Untuk mengantisipasi semua itu, diperlukan landasan politik yang strategis dan membawa maslahat kepada semua masyarakat muslim di seluruh dunia. Maka kajiankajian tentang perpolitikan Islam yang mendalam dan menyeluruh demi tercapainya kesepakatan antar golongan-golongan Islam dalam hal politik adalah keniscayaan. Tujuannya jelas, agar energi yang terlalu besar dan sangat potensial dalam tubuh Islam ini tidak terbuang percuma hanya dengan pertumpahan darah antar saudara sendiri dengan dalih klaim kebenaran (truth claim) dari masing-masing pihak. Atau, lantaran hanya ingin mendapatkan legitimasi kekuasaan politik demi kepentingan mereka sendiri dan menagacuhkan esensi keberadaan Islam yang telah diperjuangkan oleh baginda Nabi Muhammad sedemikian luhur.

\section{Konsep Dasar Politik dalam Ajaran Ahlussunnah Wal Jamaah}

Secara literal, Ahlussunnah Wal Jama'ah adalah pengikut Sunnah Nabi dan para sahabat. Istilah ini pertama kali dipakai pada abad ke-2 Hijriyyah. Dan menurut sebuah hadis, pengikut Ahlussunnah Wal Jama'ah merupakan satu-satunya "golongan yang selamat" (firqah al-Najiyah) dari 73 golongan yang ada di dalam Islam. Selama berabadabad Ahlussunnah Wal Jama'ah menjadi sebuah warisan historis yang telah pula memasuki arena politik. Sedangkan secara konstektual, para pengikut Ahlussunnah Wal Jama'ah adalah para pengikut Sunnah Nabi dan ijma' ulama'. ${ }^{10}$

Prinsip umum ajaran sosial politik Sunni adalah mengambil sikap tawasuth, tawazun, ta'addul, dan tasamuh serta al-qiyam bi al-qadim as-shalih wa al-akhdzu bi aljadid al-ashlah. Dengan prinsip ini Sunni selalu mengambil sikap akomodatif, toleran, moderat, dan menghindari sikap ekstrim dalam menghadapi spektrum budaya apapun, tak terkecuali budaya politik kekuasaan. Dalam konteks politik, sikap-sikap seperti itu dijadikan framework dan kerangka paradigmatik bagi setiap pemikiran dan tampilan politiknya. Menurut pandangan Sunni, mendirikan negara itu adalah wajib syar'i, karena syariah tidak akan bisa ditegakkan tanpa ditopang oleh kekuasaan. Inilah hujjah awal yang senantiasa ditarik oleh mazhab Sunni atau Ahlussunnah Wa al-Jamaah, terlebih

${ }^{10}$ Suaidi Asy'ari, Nalar Politik NU \& Muhammadiyah: Over Crossing Java Sentris, (Yogyakarta: LKiS, 2009), p. 102. 
ketika menghadapi krisis sosial politik kemaslahatan atau politik kebajikan demi kelangsungan umat pada umumnya.

Oleh karena itu, keberadaan kepala negara tidak hanya berfungsi menjamin keselamatan warganya, tetapi untuk kelangsungan ajaran agama. Dalam perspektif mazhab Sunni, negara adalah perwujudan dari kepemimpinan kenabian yang berfungsi meneruskan misi kenabian, yaitu memelihara agama dan mengatur pranata sosial. Dan kewajiban mendirikan negara merupakan tanggung jawab kolektif seluruh umat (fardlu kifayah). Sedangkan versi al-Ghazali, pemikir politik Sunni umumnya mencoba menguraikan relasi (hubungan) agama dan negara dengan pola nalar simbiosis mutualistik pada kerangka hubungan yang saling bergantungan (interdependent). Model bangunan pemikiran politik Sunni seperti ini tentu dilatarbelakangi oleh banyak faktor seperti sosial keagamaan, budaya, dan setting politik yang melingkupi kehidupan para tokoh Sunni. ${ }^{11}$

Begitu melegendanya paham Ahlussunnah Wal Jama'ah, telah menyebabkan banyak pihak dalam Islam yang menyandarkan paham keagamaan maupun kebijakan politiknya pada paham yang telah dianut mayoritas pemeluk Islam tersebut. Sehingga diperlukan kejelian memilih dan mempertimbangkan setiap paham yang membawa label Ahlussunnah Wal Jama'ah, tentu dengan melakukan diskusi-diskusi ilmiah yang beradab dan bertanggung jawab disertai referensi-referensi yang lengkap dan kuat, agar konsep dasar pemerintahan Islam yang rahmatan lil 'alamin bisa benar-benar terwujud.

\section{Paham Keagamaan Nahdlatul Ulama}

Nahdlatul Ulama (NU) menganut paham Ahlussunah wal Jama'ah, sebuah jalur pikir yang mengambil jalan tengah ekstrim aqli (rasionalis) dengan kaum ekstrem naqli (skripturalis). Karena itu sumber pemikiran bagi NU tidak hanya Alquran, Sunnah, tetapi juga menggunakan kemampuan akal ditambah dengan realitas empirik. Cara berpikir semacam itu dirujuk dari pemikir terdahulu, seperti Abu Hasan Al-Asy'ari dan Abu Mansur Al-Maturidi dalam bidang teologi. Sementara dalam bidang tasawuf, mengembangkan metode Al-Ghazali dan Junaid Al-Baghdadi, yang mengintegrasikan

\footnotetext{
${ }^{11}$ Ridwan, Paradigma Politik NU, pp. 7-11.
} 
antara tasawuf dengan syariat. ${ }^{12}$ Maka selain mengutamakan dasar paham keagamaannya dari Alquran dan Sunnah, NU juga mengembangkan pemikiranpemkiran terdahulu yang telah disebutkan di atas. Menurut Ahmad Zahro, NU mendasarkan paham keagamaannya kepada sumber ajaran Islam, yaitu Alquran, asSunnah, al-ijma' dan al-qiyas. ${ }^{13}$

Berbeda dengan organisasi-organisasi tradisional(is) lain, NU tidak hanya mengakui sebagai penganut paham Ahlus-Sunnah Wal-Jama'ah, tetapi juga mengembangkannya secara lebih komprehensif. Bagi ulama-ulama NU, Aswaja (kependekan dari Ahlus Sunnah Wal-Jamaah) adalah corak keberagaman umat Islam, baik pemahaman maupun praktik, yang didasarkan atas tradisionalisme mazhabiyah. Ia merupakan sistem ajaran Islam yang dijajarkan dan dipraktikkan Nabi dan para Sahabatnya. Untuk merinci lebih jelas rumusan Aswaja, ulama NU menempatkan kalam sebagai sistem kepercayaan, fikih sebagai norma yang mengatur kehidupan, serta tasawuf sebagai tuntunan dalam membina akhlak dan mencerahkan rohani, bukan sebagai ajaran yang terpisah-pisah melainkan sebagai tiga aspek yang menyatu sebagai ajaran Islam. Ulama NU telah merumuskan paham Aswaja secara lebih konkrit untuk menjadi pegangan organisasi dan warga Nahdliyin, yakni dalam i'tiqad menganut teologi Al-Asy'ari dan Al-Maturidi, dalam fikih mengikuti salah satu dari empat Imam Mazhab: Abu Hanafi, Maliki Ibnu Anas, Muhammad Idris asy-Syafi'i, dan Ahmad Ibnu Hanbal, sedangkan dalam tasawuf mengikuti ajaran Junaidi al-Baghdadi dan Abu Hamid al-Ghazali. ${ }^{14}$

Berdasarkan segi paham keagamaan, dapat dilihat dari jumlah orang mendukung dan mengikuti paham keagaman NU. Dalam hal ini bisa dirujuk hasil penelitian Saiful Mujani (2002), yaitu berkisar 48\% dan Muslim Santri Indonesia. Suaid Asyari (2009) memperkirakan ada sekitar 51 juta dari Muslim Santri dapat dikatakan pendukung Indonesia, disebut Muslim sampai 80 juta atau lebih merupakan paham keagamaannya yang sama dengan paham keagamaan NU. Meski demikian, belum tentu juga mereka ini

12 Situs Resmi Nahdlatul Ulama, "Paham Keagamaan NU” 16 Maret 2014. (online), sumber diakses dari http://www.nu.or.id/lang,id-.phpx//paham keagamaan NU. htm., 14 Maret 2015 dan 5 Agustus 2017. Lihat pula Asep Saeful Muhtadi, Komunikasi Politik, pp. 27-31.

${ }^{13}$ Ahmad Zahro, Tradisi Inteltual NU: Lajnah Bahtsul Masa'il 1926-1999, (Yogyakarta: LKiS, 2004), p. 19.

14 Djohan Effendi, Pembauran Tanpa Membongkar Tradisi, Wacana Keagamaan di Kalangan Generasi Muda NU Masa Kepemimpinan Gus Dur, (Jakarta: PT Kompas Media Nusantara, 2010), pp. 103-4. 
semua mau disebut atau berafiliasi dengan NU, baik secara keorganisasian maupun gerakan politiknya. ${ }^{15}$

Dalam perkembangan NU, munculnya gairah baru intelektualisme NU tidak lepas dari keputusan NU meninggalkan hiruk-pikuk kehidupan politik praktis dengan konsep kembali ke Khittah 1926 pada tahun 1984. Keputusan itu, seakan menekan warga dan elit NU tidak lagi disibukkan urusan-urusan politik praktis sehingga mempunyai waktu lebih banyak untuk memikirkan dan mengola-tumbuhkan peradaban kependidikan. Bahkan, terpilihnya kiai Achmad Siddiq sebagai Rais 'Aam Syuriyah dan Abdurahman Wahid sebagai Ketua Umum Tanfiziyah PB NU pada Muktamar di Situbondo tahun 1984 cukup memengaruhi perkembangan pemikiran Islam di NU dan mempunyai makna yang strategis untuk terus menjadikan NU sebagai eksemplar gerakan intelektual, bukan semata-mata sebagai gerakan politik. ${ }^{16}$

NU harus memberikan pelayanan yang lebih maksimal dari sekadar pemenuh kebutuhan warga dan pengikutnya yang semata-mata bersifat sosial-keagamaan, walaupun masih jauh dari adanya kebulatan pendapat tentang bagaimana kebutuhankebutuhan lain harus didefinisikan. Sebagian kiai berpikir tentang bagaimana mempermudah atau mengorganisir pelaksanaan haji secara lebih baik, atau bagaimana membuat orang beriman lebih mudah untuk mengetahui makanan kemasan yang halal atau haram. Tetapi kebanyakan anggota muda NU lebih berpikir dalam kerangka keadilan sosial dan pengembangan masyarakat tercerahkan berkemakmuran. ${ }^{17}$

Tujuan NU sendiri terhadap paham sosial keagamaan yang melekat adalah berlakunya ajaran Islam yang menganut faham Ahlusunnah wal-Jama'ah dalam rangka mewujudkan tatanan masyarakat berkeadilan demi kemaslahatan, kesejahteraan umat dan tercapainya rahmat bagi semseta. Untuk merealisasikan tujuan tersebut, NU melaksanakan usaha-usaha sebagai berikut:

1) Di bidang agama, NU mengupayakan terlaksananya ajaran Islam yang menganut faham Ahlusunnah Wal Jama'ah; 2) Di bidang pendidikan, pengajaran dan kebudayaan, NU mengupayakan terwujudnya penyelenggaraan pendidikan dan pengajaran serta pengembangan kebudayaan yang sesuai dengan ajaran Islam untuk

${ }^{15}$ Ahmad Asep Hidayat dkk, Studi Islam di Asia Tenggara, (Bandung: Pustaka Setia, 2014), p. 247.

16 Ibid., p. 251.

${ }^{17}$ Martin van Bruinessen, NU Tradisi, Relasi-Relasi Kuasa, Pencarian Wacana Baru, (Yogyakarta: LKiS 1994), p. 140. 
membina umat agar menjadi muslim yang takwa, berbudi luhur, berpengetahuan luas dan terampil, serta berguna bagi agama, bangsa dan Negara; 3) Di bidang sosial, NU mengupayakan dan mendorong pemberdayaan di bidang kesehatan, kemaslahatan dan ketahanan keluarga, dan pendampingan masyarakat yang terpinggirkan (mutsadl'afin); 4) Di bidang ekonomi, NU mengupayakan peningkatan pendapatan masyarakat dan lapangan kerja atau usaha untuk kemakmuran yang merata; 5) NU juga mengembangkan usaha-usaha lain melalui kerjasama dengan pihak dalam dan luar negeri yang bermanfaat bagi masyarakat banyak guna terwujudnya Khairah Ummah; 6) NU juga bercita-cita mewujudkan hubungan antar bangsa yang adil, damai, dan manusiawi, menuntut saling pengertian dan saling memerlukan. Guna mewujudkan semua itu, NU bertekad mengembangkan ukhuwah Islamiyah, ukuwah Wathoniyah, dan ukhuwah Insaniyah yang mengemban kepentingan nasional dan internasional dengan berpegang teguh pada prinsip-prinsip al-ikhlas (ketulusan), al-'adalah (keadilan), attawassuth (moderasi), at-tawazun (keseimbangan) dan at-tasamuh (toleransi), dengan tetap menjungjung tinggi semangat yang melatarbelakangi berdirinya dan prinsipprinsip yang ada dalam Qanun Asasi. ${ }^{18}$

Dalam rangka mengaplikasikan pemahaman sosial keagamaannya, NU juga memiliki tujuan-tujuan tertentu agar menjadi tolak ukur terhadap pemahaman kepada kader-kadernya dan semua masyarakat untuk menjadikan NU sebagai organisasi tradisional dengan pemikiran, pemahaman sosial keagamaan yang mengedepankan kemaslahatan umat (li maslahati al-ummati).

\section{E. Paradigma Politik dalam Nahdlatul Ulama}

Paradigma adalah kumpulan tata nilai yang membentuk pola pikir seseorang atau sebuah kelompok sebagai titik tolak pandangannya sehingga akan membentuk citra subjektif - mengenai realita - dan akhirnya akan menentukan bagaimana ia menanggapi realitas. Dalam bahasa sederhana, paradigma adalah cara pandang, pola pikir, cara berpikir. Sedangkan dalam Kamus Besar Bahasa Indonesia (KBBI) paradigma diartikan sebagai kerangka berpikir. ${ }^{19}$

18 Ibnu Manshur Dalam ADRT NU Tahun 2010, (online) sumber diakses dari http://www.muslimedianews.com/2013/10/tujuan-nu-berlakunya-ajaran-islam.html. Diakses 14 Maret 2015 dan 5 Agustus 2017.

19 Perspektif ini juga disarikan salah satunya dari cara pandang Thomas Khun dan beberapa pemikir lain di bidang filsafat pengetahuan. 
KH. Sahal Mahfudh menegaskan bahwa di dalam NU dikenal ada 3 macam paradigma politik, yaitu politik kenegaraan, kerakyatan, dan kekuasaan. Bagi NU, tegas KH. Sahal, dari 3 macam politik itu, sebetulnya politik kekuasaan (praktis) menempati kedudukan paling rendah. Pernyataan ini implisit untuk mengingatkan para politisi NU yang sudah keluar dari Khittah 1926, termasuk belakangan politisi yang belakangan ini ada menempa diri dalam perahu politik Partai Kebangkitan Bangsa (PKB), Partai Persatuan Pembangunan (PPP), PKNU, dan lain-lain.

Seiring kompleksitas perkembangan politik Indonesia, perjalanan politik NU juga menanjak-kencang. NU mulai bersentuhan dengan politik kenegaraan (kebangsaan), terutama masa-masa sesudah kemerdekaan. Persentuhan ini merupakan pengaruh gerakan nasionalisme di beberapa negara yang bergerak menuju kemerdekaan. Kontribusi politik kenegaraan NU yang paling jelas adalah dukungan Wahid Hasyim, wakil NU dalam PPKI, untuk tidak mencantumkan Piagam Jakarta dengan beberapa isinya dalam Dasar Negara kita. ${ }^{20}$

Esensi NU didirikan bukan untuk tujuan politik kekuasaan, tetapi politik (keagamaan) yang senantiasa berbasis kerakyatan. Maka, bagi umat Islam Indonesia yang menginginkan pelaksanaan praktik dan pemikiran keagamaannya dekat dengan tradisi lokalnya, kehadiran NU dinilai memberi perlindungan. Jika ini bisa disebut tindakan politik kerakyatan dalam pengertian luas, maka politik jenis inilah yang patut disebut tingkatan politik tertinggi NU. Adapun dalam politik kekuasaan, keterlibatan pertama NU ditandai dengan dukungannya terhadap pendirian Masyumi. Ketika menjadi organisasi penyangga Masyumi, tokoh-tokoh NU terlibat perebutan kekuasaan, baik untuk jabatan dalam tubuh partai maupun di luar partai (eksekutif). Politik kekuasaan masa ini diakhiri dengan perpecahan, konflik politik yang terbilang kurang mengenakkan. Keterlibatan paling pekat dengan politik kekuasaan, yaitu saat NU berdiri sebagai partai politik (1952) pasca pecah atau cerai dari Masyumi. ${ }^{21}$

Sebagai organisasi besar yang telah lama berkiprah di kancah perpolitikan tanah air, tentu saja tidak ada salahnya jika NU memiliki wadah aspirasi politik bagi warganya. Hal ini untuk menghindari perpecahan di dalam tubuh NU sendiri, walaupun keterbukaan yang ada di dalam tubuh NU dalam menyalurkan aspirasi politik warganya

20 Khamami Zada \& A. Fawaid Sjadzili, Nahdlatul Ulama: Dinamika Ideologi dan Politik Kenegaraan, (Jakarta: PT Kompas Media Nusantara, 2010), pp. 3-5.

21 Ibid., p. 5. 
selama ini sudah berjalan baik. ${ }^{22}$ Politik NU adalah politik kebangsaan, bukan politik kepentingan sesaat. Ia bukan politik parsialistik, melainkan politik paradigmatikuniversalistik. Sehingga tidak mencederai cita-cita luhur para pendiri NU dan dapat ikut serta membangun masyarakat berbasis nilai-nilai keislaman yang mempunyai jiwa nasionalisme serta kepedulian sosial yang tinggi.

Dalam rangka mewujudkan semuanya, kekuasaan bukan jalan pintas yang harus ditempuh. Ia semata salah satu media. Akan tetapi, pendekatan kultural dan sikap merakyatnya organisasi NU bisa menjadi alternatif sekaligus menumbuhkan kewibawaan tersendiri bagi NU, meskipun akhir-akhir ini NU agak terjebak dalam situasi sangat dilematis dan krusial. Di satu sisi NU tidak ingin terlibat praktis dalam perpolitikan tapi di pihak lain "syahwat politik" para tokoh NU sangat sulit dibendung. Sepertinya, karena jiwa politik dalam NU sudah mendarah daging, tampak NU tidak bisa meninggalkan kancah perpolitikan yang menawarkan kemanisan semu itu walau sejenak. Inilah yang oleh Asep Saeful Muhtadi dilanggamkan dengan lugas bahwa NU mau tidak mau memang harus berpolitik untuk menyalurkan ghirah atau energy politik sebagian umat, elit, maupun kelembagaannya.

Sebenarnya, jauh sebelum NU didirikan, titik-titik embrio kekuatan politik Islam tradisional dalam tubuh NU telah diproduksi oleh $\mathrm{KH}$. Wahab Hasbullah. Banyak aktifitas gerakan yang dilakukan $\mathrm{KH}$ Wahab Hasbullah dalam rangka mewujudkan kekuatan politik. Hasilnya adalah tumbuh lembaga-lembaga dengan sebutan Nahdlatut Tujjar, Nahdlatul Wathan, Subbanul Wathan, dan Tashwirul Afkar. Ketiga lembaga ini kelak melahirkan banyak gerakan kebajikan dengan keunikannya masing-masing. Kemudian pada tahun 1945, NU mengeluarkan Resolusi Jihad yang membakar semangat perjuangan para pembela Republik, khususnya di wilayah Jawa Timur. Melalui wakilnya di PPKI, KH. A. Wahid Hasyim, NU tegas menolak "Piagam Jakarta" demi persatuan bangsa.

Pada era 50-an, NU mengecam gerakan separatis berlabel agama seperti DI/TII di Jawa Barat, PRRI/Permesta, maupun pemberontakan Kahar Muzakar di Sulawesi Selatan yang ingin memecah NKRI. Hal ini jua yang dalam fenomena belakangan ini, terutama di Indonesia, dilakukan oleh NU, dengan mengimbangi menjamurnya gerakan HTI. Demi menjaga legitimasi pemerintahan dalam keadaan darurat, pada tahun 1953

22 Mohammad Sobary, NU dan Keindonesiaan, (Jakarta: Gramedia Pustaka Utama, 2010), pp. 15-6. 
NU memberikan gelar kepada Soekarno dengan julukan waliyyul amri al-dlaruri bi alsyaukah, sebuah pengakuan terhadap keabsahan kekuasaan nasional dalam sudut pandang agama. ${ }^{23}$

Keterikatan dan kedekatan NU dengan politik seperti hubungan orang tua dan anak. Kita tidak bisa menafikan bahwa para pendiri NU adalah tokoh-tokoh politik yang teramat cerdas dan brilian. Meskipun mereka tidak secara terang-terangan menggaungkan suara politiknya, namun sikap dan fatwa-fatwa mereka mengarah pada berlangsungnya pemerintahan yang adil. Sebab, sebagaimana telah disinggung di muka bahwa syariat tanpa ada pemerintahan yang berlaku maka tidak akan terlaksana. Dan selama menjadi organisasi sosial dan politik keagamaan, NU tidak pernah terlibat kasus-kasus pemberontakan Islam. Komitmen terhadap negara dan bangsa diletakkan di atas segala-galanya karena NU menyadari, eksistensi negara adalah hal utama bagi kehidupan agama dan manusia sesuai dengan garis Ahlus Sunnah wal Jama'ah. ${ }^{24}$

NU memiliki beberapa model politik. Dan dua model politik NU, yakni model politik kerakyatan dan kenegaraan, merupakan pengalaman paling ideal dalam sejarah NU. Mengapa? Dua model ini menjadikan NU sebagai organisasi keagamaan yang berorientasi pada kebaikan dan kepentingan umum (mashlahatul 'ammah). Meski demikian, NU ternyata relatif dinamis dalam mempertahankan dua model politik ini karena godaan politik kekuasaan, baik dari tokoh NU sendiri maupun dari luar NU. Dan seperti ditegaskan di awal bahwa keterlibatan pertama kali NU dengan politik kekuasaan adalah ketika memberikan dukungan secara organisasi terhadap pendiri (an) Masyumi. ${ }^{25}$

Keterlibatan NU terhadap politik kekuasaan bukan hanya godaan politik, melainkan adanya faktor-faktor pendorong lain kepada NU untuk memasuki ranah perpolitikan. Keterlibatan itu dimulai dari bergabungnya NU ke dalam Al Majlisul Islami 'Ala Indonesia (MIAI) bersama Sarekat Islam, Muhammadiyah, Al Irsyad dan beberapa organisasi Islam lainnya. NU juga mendukung berdirinya Gabungan Partai Politik Indonesia (GAPPI) pada tahun 1939. Namun demikian, kiprah NU, terutama dalam Masyumi tidak berlangsung lama. Persinggungan kepentingan dan konflik lama antara

${ }^{23}$ Abu Dzarrin Al-Hamidy, dkk, Sarung \& Demokrasi: Dari NU untuk Peradaban Keindonesiaan, (Surabaya: Khalista, 2008), pp. 69-70. Perhatikan pula dalam AULA, (Surabaya: Agustus, 2007), pp. 10-2.

24 Ibid., p. 5.

${ }^{25}$ Abu Dzarrin Al-Hamidy, dkk, Sarung \& Demokrasi, p. 5. 
kubu tradisional dengan modern kembali mengemuka dalam tubuh Masyumi. Pergusuran peran politik kader NU di Masyumi yang dilakukan oleh sekelompok Islam modernis dan intelektual Islam melahirkan kekecewaan politik pada kalangan NU. ${ }^{26}$

Dengan jantan NU memutuskan cerai dari Masyumi. Dan untuk menjawab keraguan dari sebagian kalangan politik kala itu, NU memutuskan menjadi partai politik dan beraksi pada pemilu 1955. NU berhasil membuktikan dirinya sebagai partai politik yang harus diperhitungkan dalam konstelasi politik nasional. Dalam pemilu itu, NU mampu menempati posisi ketiga setelah PNI dan Masyumi dengan memperoleh 45 kursi DPR (18,4\% suara). Satu sisi, hasil itu semakin meneguhkan kepercayaan diri warga NU, namun disisi lain semakin menjadi magnet untuk menyeret NU ke dalam pergelutan politik yang lebih pragmatis dan mengakibatkan khittah awal sebagai organisasi sosial keagamaan.

NU menggabungkan diri dengan Partai Persatuan Pembangunan (PPP) pada tanggal 5 Januari 1973 atas desakan penguasa Orde Baru. Mengikuti pemilu 1977 dan 1982 bersama PPP. Pada Muktamar NU di Situbondo, NU menyatakan diri untuk kembali ke Khittah 1926, yaitu untuk tidak lagi berpolitik praktis. Namun demikian, setelah reformasi 1998, muncul partai-partai yang mengatasnamakan NU. Partai Kebangkitan Bangsa (PKB) dideklarasikan oleh Abdurahman Wahid (Gus Dur) yang menjadi tokoh fenomenal. Pada Pemilu 1999 PKB memperoleh 51 kursi di DPR dan mengantarkan Abdurahman Wahid (Gus Dur) sebagai Presiden RI. Dalam pemilu 2004, PKB memperoleh 52 Kursi DPR. ${ }^{27}$

Dengan mendapatkan peluang memperoleh kursi di DPR, NU semakin jauh memasuki ranah perpolitikan dan tidak hanya menjadi ormas Islam akan tetapi menjadi organisasi politik atau parpol. Menurut Greg Fealy, tujuan politik NU saat menjadi parpol adalah 1) penyaluran dana pemerintah terhadap NU, 2) mendapat peluang bisnis, dan 3) menduduki jabatan birokrasi. ${ }^{28}$ Dengan tiga tujuan politik seperti itu, disadari atau tidak, tampaknya justru menyebabkan NU semakin tertantang dalam mewujudkan politik kerakyatan.

${ }^{26}$ Bahrul 'Ulum, Bodohnya NU apa NU DI Bodohi? Jejak Langkah NU Era Reformasi; Menguji Khittah, Meneropong Paradigma Politik, (Semarang: Ar-Ruzz Press \& PWIPNU Jawa Tengah, 2002), pp. 5580.

${ }^{27}$ Asep Ahmad Hidayat dkk, Studi Islam, p. 250.

${ }^{28}$ Greg Fealy, Ijtihad Politik Ulama: Sejarah NU 1952-1967, (Yogyakarta: LKIS, 2011), p. 165. 


\section{F. Doktrin dan Tujuan Politik Nahdlatul Ulama}

Sebagaimana ajaran Islam tradisional lain, NU mengambil gagasangagasan politik Sunni klasik sebagai rujukan teoritis utama. Kutipan dari karya-karya al-Mawardi, al-Ghazali, al-Baqillani, dan yang lainnya banyak ditemukan dalam teksteks NU. ${ }^{29}$ Itulah dasar formal pendekatan politik NU yang mirip seperti di dalam yurisprudensi Abad Pertengahan. Kebanyakan tokoh NU pada 1950-an dan 1960-an adalah produk pendidikan pesantren, yang mata ajarannya adalah ilmu fikih. Dan bagi kaum tradisionalis, fikih merupakan ratu ilmu pengetahuan. ${ }^{30}$

Prinsip-prinsip yang paling sering dijadikan dasar pengambilan keputusan politik NU dapat dibagi menjadi tiga kategori utama: kebijaksanaan, keluwesan, dan moderatisme. Ketiga kategori ini saling berkaitan dan dalam tingkatan yang berbeda berdasarkan pada prinsip-prinsip fikih. Istilah kebijakan dalam hal ini digunakan untuk pengertian yang netral, yaitu pengambilan tindakan yang kondusif bagi upaya manfaat atau menghindari kerugian. ${ }^{31}$

Ciri kedua dari pemikiran politik NU adalah sikap luwes. Keluwesan dalam pengembalian keputusan itu sebagian merupakan wujud penerapan kaidah fikih. Suatu krisis memerlukan perhitungan-perhitungan baru tentang keuntungan dan kerugian sehingga sikap atau posisi sebelumnya dapat dipertimbangkan kembali. Sedangkan moderatisme dapat diartikan sebagai suatu keinginan menghindari tindakan yang ekstrim dan bersikap hati-hati dalam bertindak dan menyatakan pendapat. Dan dalam wacana NU secara makro, gagasan tersebut digambarkan secara jelas. Perilaku moderat terutama kecenderungan untuk memilih cara yang umum disebut sebagai 'pendekatan jalan tengah', ditemukan dalam pemikiran Islam maupun ciri ideal budaya Jawa. ${ }^{32}$

\section{G. Tujuan Politik NU}

Cara yang paling jelas bagaimana politik dapat digunakan untuk mencapai tujuan Islam adalah melalui penegakan hukum dan pembuatan undang-undang. Tujuan utamanya adalah memastikan agar syariat Islam dilaksanakan sebaik-baiknya. Dalam

${ }^{29}$ Ibid., p. 65.

30 Martin Van Bruinessen, NU, Tradisi: Relasi-Relasi Kuasa dan Pencarian Wacana Baru, (Yogyakarta: LKiS, 1994), p. 168.

${ }^{31}$ Greg Fealy, Ijtihad Politik Ulama, pp. 66-7.

32 Ibid., pp. 73-7. 
hal ini, mencakup penerapan aspek-aspek hukum pernikahan dan waris, peraturan pembayaran dan penyaluran zakat, penetapan waktu pelaksanaan shalat Jumat atau kegiatan keagamaan di bulan Ramadan, dan sebagainya. ${ }^{33}$

Tujuan politik NU terdiri dari tiga bagian utama yang dalam teorinya sangat berhubungan dengan tujuan keagamaannya, seperti telah disinggung oleh Greg Fealy. Pertama, menyalurkan dana pemerintah kepada masyarakat NU, terutama untuk meningkatkan fasilitas pendidikan dan keagamaan, seperti pesantren, madrasah, dan masjid; dan juga membangun, merawat prasarana sosial, seperti klinik kesehatan, panti asuhan, dan balai pertemuan. Kedua, berusaha mendapatkan peluang bisnis dari pemerintah bagi NU dan penduduknya. Peluang semacam ini akan memberikan keuntungan langsung kepada mereka yang mampu mendapat kedudukan dan dianggap dapat membantu Islam maupun umat pada umumnya. Semakin sejahtera anggota masyarakat kian meningkat pula kemampuan mereka memenuhi kewajiban sosial dan keagamaannya, seperti menunaikan ibadah haji, membayar zakat, dan mendukung upaya peningkatan pendidikan Islam dan kesejahteraan. ${ }^{34}$

Tujuan politik ketiga adalah mendapatkan kedudukan bagi anggota NU dalam birokrasi. Selama masa kolonial, santri tradisional umumnya menjauhkan diri dari lembaga pemerintahan dan mengembangkan usaha-usaha di sektor-sektor swasta dan informal. Setelah kemerdekaan, birokrasi dipandang sebagai jalan menuju mobilitas dan status sosial. Masuknya muslim tradisional dalam birokrasi diyakini akan meningkatkan kedudukan NU di masyarakat Indonesia, sekaligus memperkuat suara umat di kalangan pemerintah. ${ }^{35}$ Tujuan politik lain yang sama pentingnya bagi NU adalah menjamin peningkatan kondisi sosial-ekonomi pendukung tradisionalisnya. Tujuan ini kadangkadang tersirat dalam literatur NU, namun jarang dibahas secara terang-terangan. Kurang ditampakkan dan diseriusi. Meski demikian, pentingnya motivasi politik ini terlihat lebih jelas dalam forum-forum partai korespondensi internal partai. ${ }^{36}$

Ternyata ketiga motivasi ini adalah asumsi bahwa kemajuan sosial dan ekonomi merupakan suatu hal yang diperlukan untuk mencapai tujuan Islam. Krisis dalam aspek material dan ketidakberdayaan politik masyarakat muslim akan menyulitkan

33 Ibid., p. 82.

${ }^{34}$ Lik Arifin Mansurnoor, Islam in Indonesia World: Ulama of Madura, (Yogyakarta: Gajah Mada University Press, 1990), p. 261.

35 Greg Fealy, Ijtihad Politik Ulama, p. 84.

36 Ibid., p. 82. 
pelaksanaan ibadah dan syiar Islam. Selain itu, muslim yang miskin tidak dapat diharapkan bisa melaksanakan rukun Islamnya, terutama menunaikan ibadah haji dan membayar zakat. Maka kaitan antara kesejahteraan masyarakat dan religiusitas terkandung dalam konsep Izzul Islam wal Muslimin, yang arti harfiahnya adalah 'keagungan Islam dan umatnya.' Ini didasarkan pada keyakinan dalam sikap dan tindakan umat Islam. Mereka harus mempunyai kebanggaan akan agamanya, berjuang menegakkan dan menyebarkan ajarannya serta menciptakan umat yang adil, makmur, dan dinamis, yang pantas sebagai penganut keyakinan yang benar. ${ }^{37}$

Konsep lain yang serupa adalah Mab'adi Khaira Umm'ah, prinsip-prinsip kebaikan bagi umat yang dirumuskan pertama kalinya oleh Machfoedz Shiddiq di akhir 1930-an. Konsep ini difokuskan pada masalah sosial-ekonomi dan bertujuan membangun kemampuan swadaya umat melalui usaha-usaha bersama. Yang melandasi konsep tersebut adalah keyakinan bahwa Islam tidak akan dapat mewujudkan aspirasi dan keagamaannya tanpa landasan ekonomi yang kuat. ${ }^{38}$ Bukankah sejak awal juga Islam sebetulnya telah mengajarkan bagaimana menata basis perekonomian demi kepentingan dan kemaslahatan umat? Spirit luhur zakat dalam Islam, menirukan alur pikir Masdar F. Mas'udi, sejatinya dimaksudkan untuk mengaktualisasikan keislaman jati-diri manusia pada dimensi kesadaran etis dan moralitas yang peka realitas sosial. Disamping terkait dengan amanah Allah SWT yang bersifat transenden juga berorientasi penuh pada pencarian Allah SWT sebagai realitas sosial yang obyektif dan imanen berbasis keadilan. ${ }^{39}$

Sungguh tidak begitu mengherankan bilamana NU merasa perlu memberikan penekanan pada aspek-aspek sosial-ekonomi, mengingat kuatnya budaya wiraswasta di kalangan umat Islam tradisional dan sudah sejak lama perhatian organisasi tercurah pada kesejahteraan materiil anggotanya. Minimal kesadaran ini dibuktikan dengan lahir dan digerakkannya Nahdlatu al-Tujjar, sebagai embrio awal keberadaan NU di tanah air. Dan menurut Ali Haidar, walaupun pada awalnya tujuan NU dicapai melalui kegiatan nonpolitik di sektor swasta, organisasi ini ternyata semakin tenggelam dalam kegiatan

37 Achmad Siddiq, Pedoman Berpikir Nahdlatul Ulama (fikiran Nahdliyah, (Jember: PMII Tjabang Djember, 1969), p. 12.

${ }^{38}$ Lihat komentar Idham Chalid dalam Buku Kenang-Kenangan MU'tamar ke XXII, p. 101.

${ }^{39}$ Lihat Masdar F. Mas'udi, Agama Keadilan, Risalah Zakat (Pajak) Dalam Islam, (Jakarta: P3M, 1993), pp. 29-30. 
politik selama 1930-an demi melindungi kepentingan ekonominya dalam persaingan dengan orang-orang Belanda dan Cina. ${ }^{40}$

Jelas bahwa pendekatan politik semacam ini berorientasi pada kepentingan, namun apakah berarti oportunis, seperti begitu sering dinyatakan para pengikut NU? Jawabnya sangat tergantung pada pendefinisian istilah 'oportunis' itu sendiri, dan ini merupakan hal yang sering diabaikan para pengkritik. Jika istilah 'oportunis' digunakan dalam pengertian yang mengacu kepada seseorang atau organisasi yang memanfaatkan setiap kesempatan, maka istilah tersebut cukup sesuai dalam menggambarkan NU. Padahal kenyataannya, istilah itu biasanya dimaksudkan untuk menyatakan secara halus bahwa NU memanfaatkan setiap kesempatan yang ada dengan cara yang 'tidak wajar.' Tetapi pernyataan ini, masih dapat dipertanyakan. Asumsi lain yang melandasi kritik-kritik, seperti 'tidak berprinsip' dan 'oportunis', yang dilontarkan terhadap NU adalah anggapan bahwa suatu prinsip lebih bersifat moral daripada praktis. Dengan demikian, penerapan prinsip moral dipandang sebagai yang membatasi lingkup tindakan pragmatis atau mementingkan diri sendiri. ${ }^{41}$ Kalau pun pendekatan politik seperti itu berorientasi pada kepentingan, namun tidak bisa serta merta NU dikategorikan sebagai oportunis, melainkan lebih pada bagaimana ia memaksimalkan kemaslahatan bagi jamaah dan umatnya. Wabilkhusus, semata memaksimalkan thariqah atau cara dalam mengaktualisasikan diri sebagai elemen sosial kebangsaan yang tak boleh pasif. Ini adalah hal wajar, lumrah, dan (mungkin) layak melekat dalam tubuh institusi keumatan yang berada dan "mengada" demi kelangsungan umat secara makro dan dalam masa yang tak terbatas.

\section{H. Peranan Ideal NU dalam Kancah Perpolitikan Bangsa}

Berkaitan dengan bentuk ideal politiknya, tentu tidak bisa lepas dari Khittah NU sendiri. Sebab, Khittah NU 1926 selama ini sering dipahami sebagai proses "depolitisasi" NU struktural. NU dituntut seratus persen kembali pada gerakan sosial kemasyarakatan tanpa sedikit pun bersentuhan apalagi masuk dalam politik praktis. NU harus jentel, berani ambil dan menerima risiko, tidak ogah-ogahan, dan ksatria dengan

40 Ali Haidar, Nahdhatul Ulama dan Islam di Indonesia: Pendekatan Fiqh dalam Politik, (Jakarta: Geramedia, 1994), p. 98.

41 Greg Fealy, Ijtihad Politik Ulama, pp. 90-1. 
kematangan paradigma sosial-etiknya. Meski sesungguhnya tak sedikit kalangan yang meragukan hal ini terjadi. Setidaknya dikarenakan beberapa faktor berikut:

Pertama, para elite NU suka berpolitik praktis. Ini memang dari sejarahnya, NU dilahirkan tidak lepas dari politik kekuasaan. Memisahkan NU dengan politik sama saja memutuskan NU dari konstruksi historisitasnya sendiri. Kedua, NU merupakan satusatunya organisasi yang memiliki basis massa terbesar di Indonesia. Karena itu, NU mempunyai daya tarik cukup kuat terhadap berbagai pihak politis. Dan mengaca pada sejarah, daripada massa yang dimiliki dimanfaatkan kelompok-kelompok politik selain NU, lebih baik kekuatan massa itu dimobilisasi sendiri. Ketika berfusi ke dalam Masyumi, NU hanya dimanfaatkan menjadi kantung-kantung suara, namun orang-orang NU dalam partai tersebut selalu menuai kekecewaan dan terpinggirkan.

Ketiga, NU kultural harus memiliki jalur politik secara resmi karena ketidakmandirian politik warganya. Warga NU yang pada umumnya adalah masyarakat awam, tidak serta merta percaya diri mengambil keputusan politik secara otonom dan independen, kecuali bertanya terlebih dahulu kepada tokoh (kiai). Tradisi ini cukup mengakar di kalangan konstituen NU. Sebab kiai, dalam istilah Asep Saeful Muhtadi, di kalangan NU itu seperti "makelar simbol" yang dapat menerjemahkan tarikan bahasa politik yang mudah dipahami oleh konstituen (umat) dengan sentuhan nilai-nilai agama. ${ }^{42}$ Disini tampak peran politik NU sebagai pendidik politik yang mengajarkan kedewasaan berpolitik sesuai dengan ideologi NU yang telah ditetapkan founding father/mu'assis NU.

Keempat, jika Khittah NU dipahami sebagai tidak tahu menahunya NU secara struktural terhadap politik masing-masing warganya, maka NU sendiri akan mendapat kerugian. Kekuatan NU akan tersebar dalam banyak partai. Kekuatan NU akan tercerai berai dan menjadi kecil. Sebab, dalam partai-partai tersebut ideologi warga NU tidak akan utuh lagi, bahkan tergerus oleh ideologi partai-partai politik yang diikutinya. Ini akan menyebabkan menguapnya ideologi NU dan hilangnya militansi kader-kader NU dalam perjuangan pembebasan. ${ }^{43}$ Maka dibutuhkan usaha-usaha mereformulasi Khittah NU 1926. Khittah 1926 harus dipahami sebagai strategi politik, sebagaimana yang sering digunakan Gus Dur ketika kondisi politik waktu itu tidak memungkinkan NU

\footnotetext{
${ }^{42}$ Asep Saeful Muhtadi, Komunikasi Politik, p. 44.

${ }^{43}$ Abu Dzarrin Al-Hamidy dkk, Sarung \& Demokrasi, pp. 77-8.
} 
mengepakkan sayap dari alur politik praktis yang sangat sempit. Gus Dur sungguh lihai dan langkahnya selalu tepat serta lebih strategis untuk menghindari kebuntuan gerakan pada masa-masa tertentu. Inilah langkah non-politis dari (kiai) politik NU. Jauh di luar itu, Khittah NU 1926 juga harus dipahami sebagai upaya mengembalikan dunia politik praktis sebagai bagian yang tidak terpisahkan dengan agenda besar politik kebangsaan yang digagas NU sejak awal.

Dilihat dari telisikan di atas, berarti politik praktis NU harus menjadi perpanjangan tangan tujuan politik kebangsaan NU dalam rangka pemberdayaan komunitas NU. Gerak politik praktis tidak boleh keluar dari koridor agenda besar ini. Jika orientasi parpol terlepas dari tujuan besar politik kebangsaan NU berarti parpol NU telah mengingkari semangat khittahnya. Untuk itu, tujuan politik praktis juga merupakan agenda dalam memberdayakan masyarakat dari segi ekonomi, intelektualitas, spiritualitas, dan semangat nasionalisme sebagaimana tercermin dalam pilar-pilar yang menjadi pendorong berdirinya NU.

Dalam konteks kekinian, khittah harus dipahami sebagai upaya membela bangsa Indonesia, utamanya warga NU dari berbagai ketertindasan. Khittah NU harus terinternalisasi dalam sikap konsisten terhadap ajaran ASWAJA NU yang dirumuskan sebagai manhajul fikr yang tasamuh, tawasuth, tawazun, dan ta'adul. ${ }^{44}$ Disamping itu pula, untuk menghentikan terjadinya tarik menarik dan perbedaan interpretasi khittah maka diperlukan adanya pedoman berpolitik bagi warga NU sendiri. Pedoman tersebut dapat dirumuskan menjadi sembilan rumusan politik NU yang telah disepakati pada muktamar NU tahun 1989, sebagai berikut: 45

1. Berpolitik bagi NU mengandung arti keterlibatan warga negara dalam kehidupan berbangsa dan bernegara secara menyeluruh sesuai Pancasila dan UUD 1945.

2. Politik bagi NU adalah politik kebangsaan dan menuju integrasi bangsa dengan langkah-langkah yang senantiasa menjunjung persatuan dan kesatuan untuk mencapai cita-cita bersama.

3. Politik bagi NU adalah pengembangan nilai-nilai kemerdekaan yang hakiki dan demokratis, mendidik kedewasaan bangsa untuk menyadari hak, kewajiban, dan tanggung jawab mencapai kemaslahatan bersama.

4. Berpolitik bagi NU haruslah dilakukan dengan moral, etika, dan budaya yang ber-Ketuhanan Yang Maha Esa, berkeperimanusiaan yang adil dan beradab, menjunjung tinggi persatuan Indonesia, berkebijaksanaan dalam permusyawaratan/perwakilan dan berkeadilan sosial bagi seluruh rakyat Indonesia.

5. Berpolitik bagi NU haruslah dilakukan dengan kejujuran murni dan moral agama, konstitusional, adil sesuai dengan peraturan dan norma-norma yang disepakati, serta dapat mengembangkan mekanisme musyawarah dalam memecahkan masalah bersama.

\footnotetext{
${ }^{44}$ Ibid., pp. 78-9.

45 Bahrul 'Ulum, Bodohnya NU apa NU Dibodohi?, pp. 174-5.
} 
6. Berpolitik bagi NU dilakukan untuk memperoleh konsensus nasional, dan dilakukan sesuai dengan akhlaqul karimah sebagai pengamalan ajaran Islam Ahlussunnah Wal Jama'ah.

7. Berpolitik bagi NU, dengan dalil apapun, tidak boleh dilakukan dengan mengorbankan kepentingan bersama dan memecah belah persatuan.

8. Perbedaan pandangan diantara aspirasi-aspirasi politik warga NU harus tetap berjalan dalam suasana persaudaraan, tawadlu', dan saling menghargai satu sama lain sehingga di dalam berpolitik itu tetap dijaga persatuan dan kesatuan di lingkungan NU.

9. Berpolitik bagi NU menuntut adanya komunikasi kemasyarakatan timbal balik dalam pembangunan nasional untuk menciptakan iklim yang memungkinkan perkembangan organisasi kemasyarakatan yang lebih mandiri dan mampu melaksanakan fungsinya sebagai sarana masyarakat untuk berserikat, menyalurkan aspirasi serta berpartisipasi dalam pembangunan.

Mengkaji wacana tentang bentuk ideal peranan NU dalam kancah politik tentu bukan hal yang sulit. Sebab NU sudah pernah merasakan bentuk paling idealnya, yakni ketika masih awal berdirinya di era awal perjalanan bangsa. Meskipun, dinamika sekarang adalah bentuk ideal dalam kancah politik pada yang berbeda dengan periode dulu. Sebuah tugas yang berat dan rumit jika harus menentukan bentuk paling idealnya NU dalam kancah politik, namun bukan tidak mungkin bentuk ideal itu bisa dicapai ketika semua elemen yang ada dalam diri NU bahu-membahu dan berupaya bersamasama berbuat sesuatu mencapai bentuk ideal yang di cita-citakan. Lalu tawaran politik kenegaraan dan kerakyatan adalah tawaran yang patut diapresiasi dan didalami lebih jauh, diamalkan jika itu benar-benar bisa membawa manfaat. Jika dilihat dari sudut pandang politik, politik kenegaraan dan kerakyatan adalah jalan keluar yang tepat serta tidak membatasi para warga Nahdliyin yang ingin tetap menyalurkan hasrat politiknya. Sebab dalam kedua politik tersebut kita masih tetap bisa berpolitik dengan memanfaatkan suara rakyat serta jiwa nasionalisme untuk ikut serta berkontribusi membawa kemajuan bangsa dan negara Indonesia di masa yang akan datang.

\section{Penutup}

Mari kita refleksikan kembali bagaimana politik dalam tubuh NU yang mencakup tiga jenis politik, yaitu politik kenegaraan, kerakyatan, dan praktis. Dari ketiga jenis itu, politik kenegaraan merupakan suatu hal yang harus diprioritaskan. Karena menilik sejarah berdirinya, NU merupakan organisasi yang melahirkan tokoh-tokoh yang ikut andil dalam merumuskan prinsip-prinsip dasar kenegaraan. Hal ini bisa kita lihat, misalnya, kontribusi KH. Wahid Hasyim yang menolak pencantuman piagam Jakarta sebagai dasar negara. Sudah seyogianya peranan NU yang paling ideal dalam kancah perpolitikan di Indonesia adalah bersikap netral terhadap kekuatan politik-politik lain sembari menengok sejenak ke bawah betapa warga Nahdliyin yang menjadi sumber 
Mawa'izh

utama eksistensi NU seolah tak mendapat perhatian dari para pembesarnya karena disibukkan dengan keasyikan mereka dalam permainan politik praktis.

Oleh karena itu, kerangka ideal NU sebagai jam'iyyah diniyah ijtima'iyyah (organisasi keagamaan dan kemasyarakatan) harus terus diperkuat sehingga tidak terlemahkan oleh godaan politik praktis yang bisa melemahkan organisasi keagamaan. Semangat dan kerangka ini bisa terjadi bukan saja bagi NU namun pada ormas-ormas Islam lain yang terus mencari eksistensi dirinya dalam tataran sosial kebangsaan. Dari sinilah artikulasi sosio-politik sebagai jam'iyyah diniyah ijtima'iyyah akan bertumbuh dengan paradigmatik. 


\section{DAFTAR PUSTAKA}

Al-Hamidy, Abu Dzarrin, dkk. Sarung \& Demokrasi: Dari NU untuk Peradaban Keindonesiaan. Surabaya: Khalista, 2008.

Ali, As'ad Said. Pergolakan di Jantung Tradisi, NU yang Saya Amati. Jakarta: LP3ES, 2008.

Asy'ari, Suaidi. Nalar Politik NU \& Muhammadiyah: Over Crossing Java Sentris. Yogyakarta: LKiS, 2009.

AULA, Agustus, 2007.

Baso, Ahmad, Civil Society versus Masyarakat Madani, Arkeologi Pemikiran "Civil Society" dalam Islam Indonesia, Bandung: Pustaka Hidayah, 1999.

Bruinessen, Martin Van, NU Tradisi: Relasi-Relasi Kuasa dan Pencarian Wacana Baru, Yogyakarta: LKiS, 1994.

Chalid, Idham, dalam Buku Kenang-Kenangan Mu'tamar ke XXII

Chumaidy, H.A. Chozin, Etika Politik dan Esensi Demokrasi, Jejak Pemikiran Demokratisasi Politik Indonesia, Jakarta: Pustaka Indonesia Satu, 2006.

Effendi, Djohan, Pembauran Tanpa Membongkar Tradisi, Wacana Keagamaan di Kalangan Generasi Muda NU Masa Kepemimpinan Gus Dur, Jakarta; PT Kompas Media Nusantara, 2010.

Fealy, Greg, Ijtihad Politik Ulama, Sejarah NU 1952-1967, Yogyakarta: LKIS, 2011.

Feillard, Andree, NU vis-à-vis Negara, Pencarian Isi, Bentuk dan Makna, Yogyakarta: LKiS, 1999.

Haidar, Ali, Nahdhatul Ulama dan Islam di Indonesia: Pendekatan Fiqh dalam Politik, Jakarta: Geramedia, 1994.

Hidayat, Asep Ahmad, dkk., Studi Islam di Asia Tenggara, Bandung: CV Pustaka Setia, 2014.

Karim, A. Gaffar, Metamorfosis NU dan Politisasi Islam Indonesia, Yogyakarta : LKiS, 1995.

Mahatma, Masmuni, NU 2 Versi, Dari Pergulatan Menuju Kejayaan, Bandung: Pusaka Publisher, 2008.

Mansurnoor, Lik Arifin, Islam in Indonesia World: Ulama of Madura, Yogyakarta: Gajah Mada University Press, 1990.

Manshur, Ibnu, Dalam ADRT NU Tahun 2010, (online) sumber diakses dari http://www.muslimedianews.com/2013/10/tujuan-nu-berlakunya-ajaranislam.html. Diakses 14 Maret 2015 dan 5 Agustus 2017.

Mas'udi, Masdar F, Agama Keadilan, Risalah Zakat (Pajak) Dalam Islam, Jakarta : P3M, 1993.

Muhammad, Yusuf, Mudzarah Jam'iyyah, Dentuman Kritisisme-Ideologis, Bandung: Media Cendekia, 2003.

Muhtadi, Asep Saeful, Komunikasi Politik Nahdhatul Ulama: Pergulatan Pemikiran Politik Radikal dan Akomodatif, Jakarta: LP3ES, 2004. 
Ridwan, Paradigma Politik NU: Relasi Sunni-NU dalam Pemikiran Politik, Yogyakarta: Pustaka Pelajar, 2004.

Siddiq, Achmad, Pedoman Berpikir Nahdlatul Ulama (fikiran Nahdliyah), Jember: PMII Tjacabg Djember, 1969.

Situs Resmi Nahdlatul Ulama, "Paham Keagamaan NU” 14 Maret 2015. (daring), sumber diakses dari http://www.nu.or.id/lang,id-.phpx//paham keagamaan NU. htm. Diakses 14 Maret 2015 dan 5 Agustus 2017.

Sobary, Mohammad, NU dan Keindonesiaan, Jakarta: Gramedia Pustaka Utama, 2010.

Soon, Kang Young, Antara Tradisi dan Konflik: Kepolitikan Nahdlatul Ulama, Jakarta: UIPress, 2007.

Suroso, Eko Maulana Ali, Energi Agama dalam Kuasa, Merapikan Nilai-Nilai Agama dalam Pemerintahan, Bandung: Mutiara Press, 2008.

Zada, Khamami \& A. Fawaid Sjadzili, Nahdlatul Ulama: Dinamika Ideoligi dan Politik Kenegaraan, Jakarta: PT Kompas Media Nusantara, 2010.

Zahro, Ahmad, Tradisi Inteltual NU: Lajnah Bahtsul Masa'il 1926-1999, Yogyakarta: LKiS, 2004.

Wahid, Marzuki, dkk, Dinamika NU, Perjalanan Sosial dari Muktamar Cipasung (1994) ke Muktamar Kediri (1999), Jakarta : Kompas-Lakpesdam NU, 1999. 